2009年 2 月2論文受付

論文受理

2009年 11 月20日

Code No. 251

\section{6 列 MDCT における 小児体幹部撮影条件の基礎的検討}

二俣芳浩・高橋靖智・菊地隆浩・杉山 淳

JA 北海道厚生連帯広厚生病院医療技術部放射線技術科

\section{緒 言}

1990 年代後半に開発された multidetector-row computed tomography $(\mathrm{MDCT})^{1)}$ は, 単列検出器のへ リカル CT に比べ短時間に薄いスライスで広範囲の撮 影が可能で, 時間分解能および体軸方向の空間分解 能が格段に向上した．また小児における CT 検査でも， スキャン時間および検査時間が短縮し，検査時の鎮 静の必要性が減り, 多少の体動や呼吸停止不良下に おいても許容できる画質が得られるようになった22. そのような CT 検査への利便性が高まる一方, $\mathrm{X}$ 線 被曝に関して野坂は, 小児の CT 検査の多くは成人 の条件で撮影されており, 小児は成人よりも体格が 小さく, 同じ撮影条件を適応した場合に, 臓器あたり の被曝量は成人の $2 \sim 5$ 倍になることや小巟 $\mathrm{CT}$ 撮影 は低い管電流でも検査可能であることを考慮する
と, リスクマネージメントの観点からも過剰な被曝を 防ぐための条件設定が必要であると報告している31. 検査時に対象が小児であれば当然成人より撮影条件 を低く設定しようと考えるが，では実際どのぐらいの 条件で撮影を行うことが適正なのかという尺度は，さ まざまな見解があり意見が分かれるところである，以 上のことから, 小児体幹部 CT 検査における撮影条 件の基礎的検討にあたり，それらを念頭においた被 曝低減が重要と考えられる。 また同時に臨床へ適応 された場合, 検査の再現性ならびに診断能も担保さ れた画質であることが求められる.

今回われわれは，適切な小児撮影条件を導き出す ために，各物理特性を測定比較するとともに，成人 腹部 CTにおける適切な被曝線量を論じるうえで肝 臓の標準偏差 (standard deviation: S.D.)を用いた文献

\title{
Overview of the Infant Body Part Photography Condition Using 16-rows Multi- detector CT
}

\author{
Yoshihiro Futamata, Yasutomo Takahashi, Takahiro Kikuchi, and Sunao Sugiyama \\ JA Hokkaidoukouseiren Obihiro Kousei Hospital, Medical Technology Section, Radiation Tech- \\ nological Department
}

Received February 26, 2009; Revision accepted November 20, 2009; Code No. 251

\section{Summary}

In infant CT scans, it is important to minimize radiation exposure without lowering the quality of the diagnosis. Therefore, appropriate parameters for infant CT scan should be considered at each institute. In order to determine parameters for infant body CT, we measured the physical characteristics of our current CT machine and evaluated scan parameters as S.D. below 10 on the basis of literature recommendations, which say that we should adopt S.D. of the liver when treated with a radiation exposure dose in an adult abdominal CT scan. As a result, the ideal parameters were $90 \mathrm{kV}$ tube voltage, ultra fast detail resolution, B kernel, and Eff.mAs value calculated from patient body width. Infant body CT scans with the mentioned parameters resulted in an S.D. below 10, and this is thought to be applicable to further examinations.

Key words: 16-rows multidetector CT, radiation exposure reduction, the infant body part photography condition, tube voltage, low-contrast resolution

別刷資料請求先： $\bar{\top} 080-0016$ 北海道帯広市西 6 条南 8 丁目 1 番地

$\mathrm{JA}$ 北海道厚生連帯広厚生病院 医療技術部放射線技術科 二俣芳浩 宛 


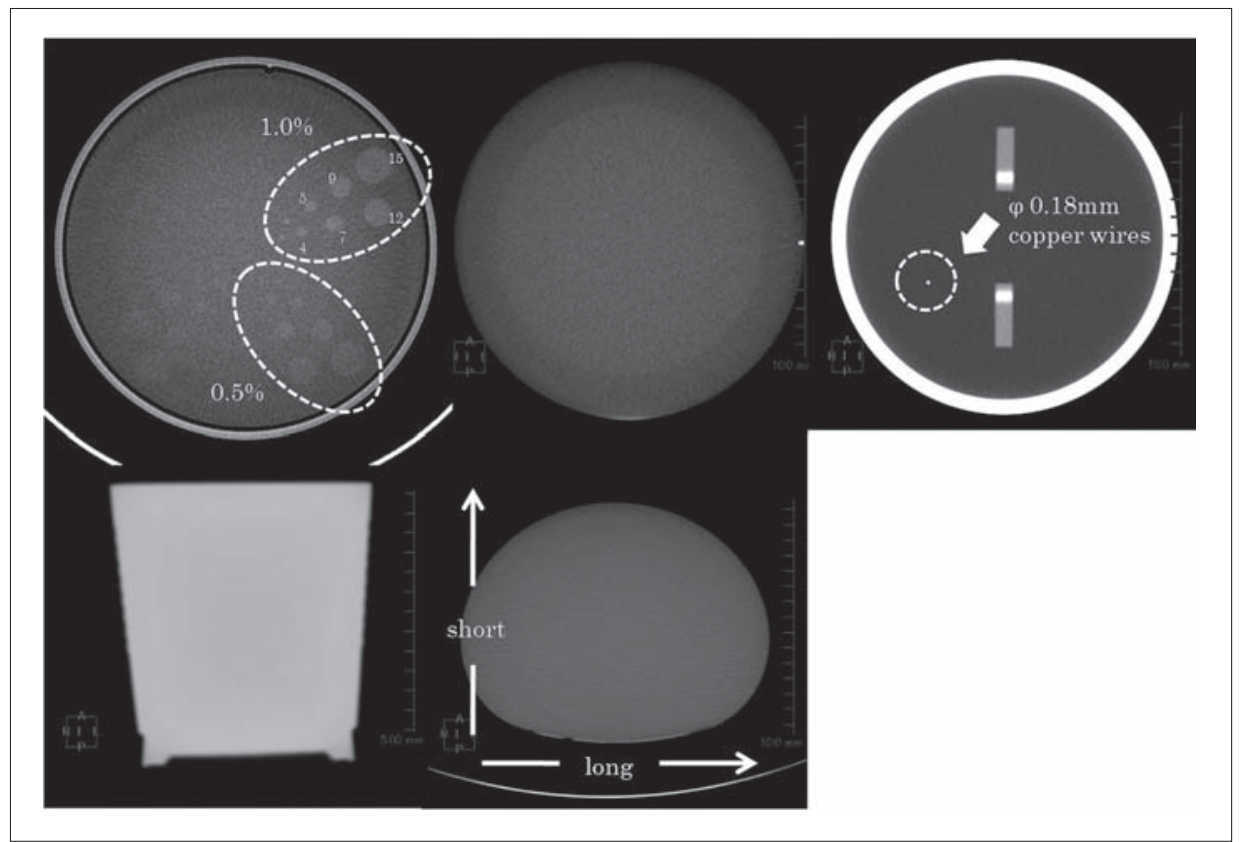

Fig. 1 Phantom.

(a) Low contrast resolution evaluation phantom

(b) Image noise measurement phantom

(c) MTF metric phantom

(d) HU-I phantom (examining the relation between CT numbers and iodine content)

(e) Elliptic water phantom

に準じ4, 5)，基礎的検討の段階から S.D. が 10 以下に なるような撮影条件について検討したので報告する。

\section{1. 方 法}

\section{1-1 使用装置および機器}

X 線 CT 装置 : Philips 社製 BrillianceCT16(Ver. 2.02)

ワークステーション：AZE 社製 Virtual Place

Advance Plus (Ver. 2.03)

低コントラスト評価ファントム：ファントムラボラ トリー社製 Catphan 412-263(Fig. 1a)

ノイズ評価ファントム：ファントムラボラトリー社 製 Catphan 412-486(Fig. 1b)

MTF 測定ファントム：Philips 社製システム標準 ファントム (Fig. 1c)

HU-I ファントム：CT 值ヨード量依存性確認用自作 ファントム (Fig. 1d, Table 1)

楕円ファントム：ゴム風船に水道水を入れた自作 ファントム(Fig. 1e, Table 2)

\section{1-2＼cjkstart評価項目および評価方法}

CT 撮影時に設定可能なパラメー夕は, Resolution, collimation，管電圧，実効電流時間積 (Eff.mAs)，スラ イス厚, Kernel, Beam Pitch(以下 Pitch)が挙げられる. 当院では，スライス厚を $5 \mathrm{~mm}$ thickness としており特 殊な検査の場合を除き detector collimation は，装置
の制約上 $16 \times 1.5 \mathrm{~mm}$ としている. またPitch は, 今回 小児を対象としているので撮影時間を考慮し，SP filter を入れ 3D 再構成可能な最大の Pitch 1.313 固定 とした。

上記以外の撮影パラメータを決定するために，1） 管電圧，2)Resolution，3)撮影線量の 3 点について基 礎的検討を行った. なお weighted computed tomography dose index(CTDIw)については, CT コンソール上に 表示されたもの（ 測定值)を使用し，マトリクスは $512 \times 512$ を使用した。

用語として, Philips 社製 Brilliance CTにおける Resolutionは, FOV および Rotation speed の制御を 行っている. [今回使用した Brilliance CT 16 の場合, Ultra fast detail(Ufd)は，最大 FOV 250 mm，最短 Rotation speed $0.42 \mathrm{sec}$, Ultra fast(Uf)は, 最大 FOV $500 \mathrm{~mm}$, 最短 Rotation speed $0.42 \mathrm{sec}, \quad$ Standard $(\mathrm{Std})$ は，最大 FOV $500 \mathrm{~mm}$, 最短 Rotation speed $0.75 \mathrm{sec}$ となって いる]. またEff.mAs は, 装置特有の撮影パラメータ であり, mA $\times$ Rotation time/Pitch で表される6).

\section{1-2-1 管電圧}

管電圧 $90 \mathrm{kV}, 120 \mathrm{kV}$ における下記項目に関し比 較検討を行った

\section{A) 低コントラスト分解能}

低コントラスト評価ファントムを各条件 (Table 3) （ただし Eff.mAs は，Std で設定可能な最小の值であ 
Table 1 lodine content of HU-I phantom

\begin{tabular}{cc}
\hline \hline phantom name & lodine content $(\mathrm{mg} / \mathrm{ml})$ \\
\hline d1 & 2.97 \\
d2 & 5.88 \\
d3 & 8.74 \\
d4 & 11.54 \\
d5 & 14.29 \\
d6 & 16.98 \\
d7 & 19.63 \\
\hline
\end{tabular}

Table 2 Diameter of elliptic phantom

\begin{tabular}{ccc}
\hline phantom name & $\begin{array}{c}\text { long diameter } \\
(\mathrm{mm})\end{array}$ & $\begin{array}{c}\text { short diameter } \\
(\mathrm{mm})\end{array}$ \\
\hline e1 & 143 & 131 \\
e2 & 160 & 147 \\
e3 & 175 & 160 \\
e4 & 185 & 175 \\
e5 & 200 & 184 \\
e6 & 220 & 202 \\
\hline
\end{tabular}

Table 3 Exposure table

\begin{tabular}{|c|c|c|c|c|}
\hline & $\begin{array}{l}\text { image noise } \\
\& \text { low contrast } \\
\text { resolution }\end{array}$ & $\begin{array}{c}\text { resolution } \\
\text { characteristics }\end{array}$ & $\begin{array}{l}\text { iodine contraset } \\
\text { medium quality }\end{array}$ & $\begin{array}{l}\text { the relationship between } \\
\text { image noise and mAs while using } \\
\text { phantoms of various size }\end{array}$ \\
\hline tube voltage $(\mathrm{kV})$ & 90,120 & 120 & & 90,120 \\
\hline Eff.mAs value & 35-max Eff.mAs & \multicolumn{2}{|c|}{200 Eff.mAs } & 20-260 Eff.mAs \\
\hline Resolution & Std & Ufd, Uf, Std & Std & Ufd \\
\hline slice thickness $(\mathrm{mm})$ & 5 & 2 & \multicolumn{2}{|r|}{5} \\
\hline Kernel & $A, B, C$ & $A, B, C$ & \multicolumn{2}{|r|}{$\mathrm{B}$} \\
\hline Pitch & \multicolumn{3}{|c|}{0.688} & 0.938 \\
\hline DFOV $(\mathrm{mm})$ & 200 & 80 & 100 & 250 \\
\hline
\end{tabular}

Ufd: Ultra fast detail, Uf: Ultra fast, Std: Standard

る 35 Eff.mAs か ら 50，100，150，200，300，350， 400, 500, 600, 700 Eff.mAs とした)で撮影し, どこ まで識別可能であるか評価を行った。評価方法は， 得られた画像に対して事前にその方法を説明された 放射線技師 5 名 (経験年数 $5 \sim 8$ 年)が各自単独で視 覚的に行った。なお，ここでの視覚的評価とは，ファ ントム内部にあるコントラストが異なる部分の大きさ を評価者が認識し，その径の計測を行い，そこで実 際の径 $\pm 10 \%$ を評価可能なものとした. また評価值 は，上記の評価方法で得られた 5 名の結果から，そ の条件下での最も低い值とした。

B) 画像ノイズ

ノイズ評価ファントムを各条件 (Table 3) で撮影 し, 約 10.000 ピクセルの正方形 $\left(39 \times 39 \mathrm{~mm}^{2}\right)$ の関心 領域(region of interest: ROI)をファントムの中心およ びファントム中心から $2 / 3 r(r$ : ファントムの半径)に 4 力所設定し, ROI 内の CT 值の S.D. を測定して加算 平均した。

C) ヨード造影剤濃度と CT 值の関係

各管電圧を変化させた時に, ヨード造影剂濃度に 応じてどのような CT 值を示すか確認するため, HU-I ファントムを各条件 (Table 3) で撮影し, 約 3.900 ピクセルの正方形 $\left(10 \times 10 \mathrm{~mm}^{2}\right)$ の ROI をファン
トムの中心およびファントム中心から $1 / 2 \mathrm{r}$ に 4 力所設 定し, ROI 内の CT 值を測定して加算平均した.

\section{1-2-2 Resolution}

Resolution(Ufd, Uf, Std)において，腹部用標準関 数 A， B ，Cの MTF の比較検討を行った.

まずMTF 測定ファントムを各条件(Table 3)で撮影 し, 得られた画像から線形強度分布 (line spread function: LSF)を求め, フーリエ変換によって変調伝達関 数 (modulation transfer function: MTF)を算出した. な お解析ソフトには, 金沢大学医薬保健研究域保健学 系の市川勝弘氏が作成したフリーソフトを使用した (http://www.owari.ne.jp/ ₹kitikawa/).

\section{1-2-3 撮影線量}

Eff.mAs 設定時に実際撮影された画像が，S.D.10 以下になるような条件について，楕円ファントム e1-e6 での画像ノイズと Eff.mAs の関係における検討 を行った。 まず楕円ファントム e5 を各条件(Table 3) （ただし Eff.mAs は，Ufd で設定可能な最小の值であ る 20 Eff.mAs から始め 10 ずつ変化させ 260 Eff.mAs まで測定した)で撮影し，約 1.600 ピクセルの正方形 $\left(20 \times 20 \mathrm{~mm}^{2}\right)$ の ROI をファントムの中心およびファン トム中心から $2 / 3 \mathrm{R}(\mathrm{R}$ : 楕円ファントム長径の $1 / 2)$ に 4 カ 所設定し, ROI 内の CT 值の S.D. を測定して加算平 
均した

次に楕円ファントム e1-e6 と Eff.mAs の関係を確 認するため, 各条件 (Table 3) (ただし管電圧は $90 \mathrm{kV}$ のみとし, Eff.mAs は 50 Eff.mAs から 10 ずつ変化さ せ 200 Eff.mAs まで測定した)で撮影し, 上記と同様 の方法で S.D. を算出した.

\section{1-3 臨床画像における S.D. の測定}

方法 1-2-1 から 1-2-3 によって算出された撮影条件 により，検査を施行した患者 24 例（男性 15 例，女性 9 例，平均年齢 5.3 歳，ただし経過観察で検査を施 行している同一患者の場合，1回の検査ごとに 1 例と したについて，臨床画像におけるS.D.の測定を行 い,この值が目的とする S.D. 10 を超えない值を示す か検証した。測定方法は，門脈左枝臍部を含むアキ シャル画像の前後 3 スライスを選択し，ストリーク アーチファクトが発生しやすい胁骨周囲を避けて肝 右葉, 肝左葉, 大動脈の 3 点に約 120 ピクセルの円 形(直径 $6 \mathrm{~mm}$ )の ROI を設定し，S.D. を測定して加 算平均した (Fig. 2).

なお統計学的検定は $\mathrm{t}$ 検定を用い，危険率 $5 \%$ 以 下を有意な差とした。

\section{2. 結 果}

\section{2-1 管電圧}

A) 低コントラスト分解能

$90 \mathrm{kV}, 120 \mathrm{kV}$ ともにEff.mAs の増加に比し評価 值が向上した。また CT 值 1\%の識別可能な Eff.mAs での CTDIw は，双方とも有意な差を認めなかった。

しかしファントム内の $1 \%$ かつ $9 \mathrm{~mm}$ 以下の識別が可 能であった条件に着目してみると, $90 \mathrm{kV}$ では 150 Eff.mAs, $120 \mathrm{kV}$ では 100 Eff.mAs となり, $90 \mathrm{kV} の$ 方がCTDIwを低く抑えられていることが分かった。

また Kernelの比較では，90 kV，120 kV ともに有 意な差を認められなかった(Fig. 3, Table 4, 5).

B) 画像ノイズ

$90 \mathrm{kV}, 120 \mathrm{kV}$ ともに Eff.mAs の増加に比し S.D. も 低い值を示した。また Kernel の比較では，Kernel A が最も低く，次いでB が約 10\%，Cが約 $30 \%$ という ような順でノイズ量の増加傾向を示した（Fig. 4，5).

C) ヨード造影剤濃度と CT 值の関係

$90 \mathrm{kV}, 120 \mathrm{kV}$ でのCT 值の比較では, どの濃度 においても $90 \mathrm{kV}$ のほが約 $25 \%$ 高い值を示し，有 意な差を認めた(Fig. 6).

\section{2-2 Resolution}

Resolution 間での MTF 比較では，同一 Kernel 間 においてUfd およびStdについて有意な差を認めな かったが, Ufのみほかより劣る結果となり有意な差

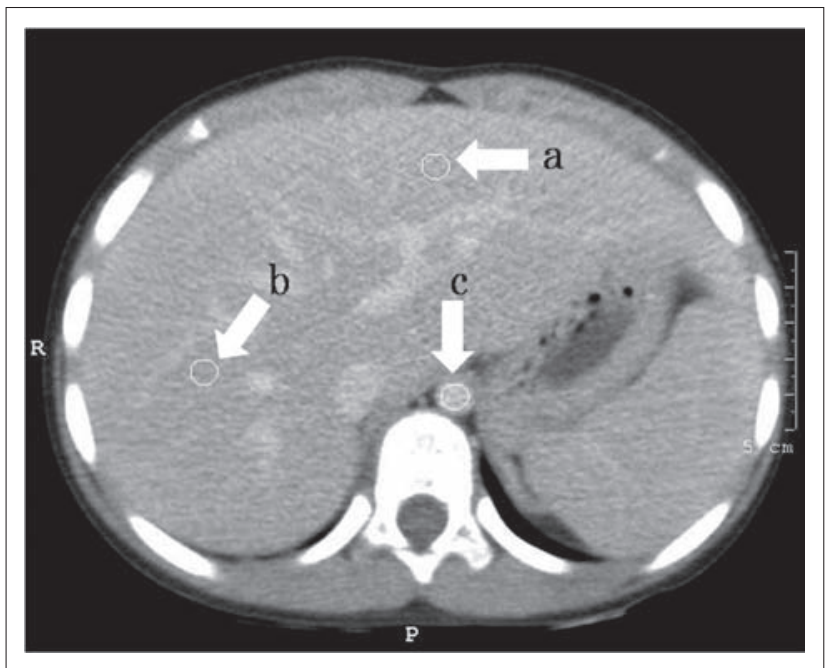

Fig. 2 ROI of measuring S.D.

(a) right lobe of liver

(c) aorta

を認めた。またUfd および Stdの Kernel A は, Uf の Kernel Cとほほ同等であった。

同一 Resolution での Kernel の MTF 比較では, Kernel A が最も低く, 次いで B, Cの順となった (Fig. 7〜9).

\section{2-3 撮影線量}

$90 \mathrm{kV}, 120 \mathrm{kV}$ ともに Eff.mAs の上昇に伴い S.D.は, 低くなる傾向を示した。 また楕円ファントム e1-e6に 対しEff.mAs を変化させて，その他のパラメータを 同一条件で撮影した場合，ファントム径が大きくなる ほど高いS.D.を示した。（Fig. 10，11）

また S.D. 10 が得られる楕円ファントム e1-e6の長 径に対応するEff.mAsより近似曲線を作成した。 こ れを使用して，位置決め画像で実際の体幅を計測 し，1-3 の検討を行う際にEff.mAs の推定に使用する こととした(Fig. 12).

\section{2-4 臨床画像における S.D. の測定}

今回の検討から得られた撮影条件で撮影した 24 例について，計測した 3 点におけるそれぞれの平均 S.D. は, 肝右葉が7.78, 肝左葉が7.55, 大動脈が 9.79 であった。また，それらをすべて合わせた平均 S.D.は 8.37 となった。

\section{3. 考 察}

2005 年に報告された小児 CT ガイドラインでは, $\mathrm{CT}$ 検査にあたっては適応を㛜密に検討し小児のため の撮影条件を適用し, CT 装置の品質管理に努めるこ ととされている7)。 またDonnelly らは患者の体重が $40 \mathrm{IB}$ (ポンド, $18 \mathrm{~kg}$ ) 以下の場合の胸腹部 CT は 100 
$90 \mathrm{kV}$
150Eff.mAs

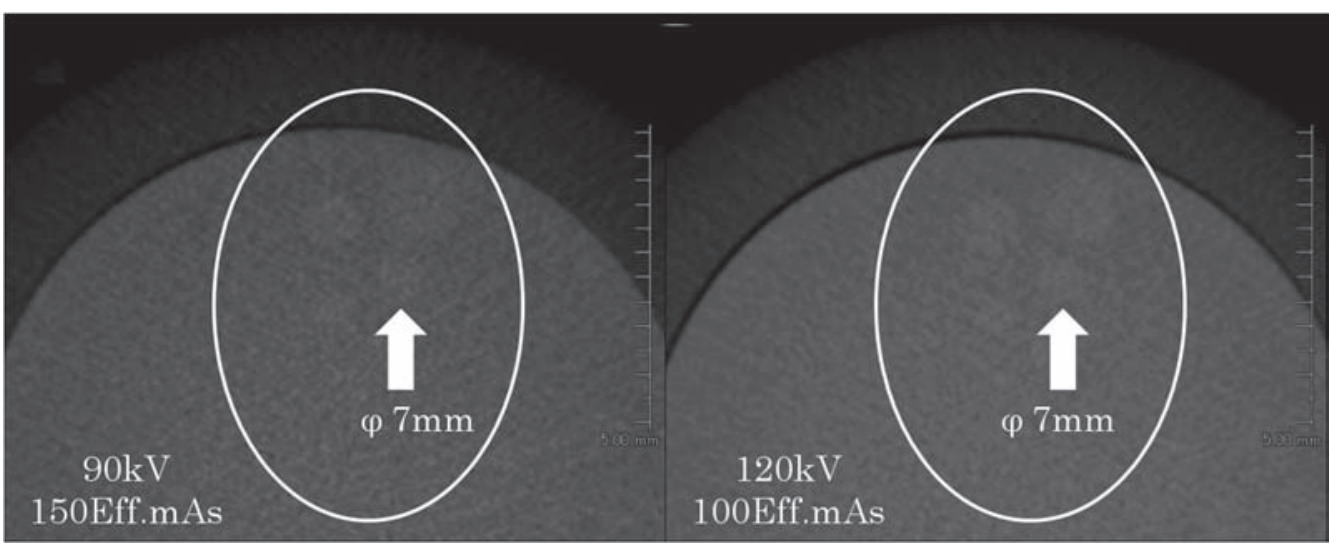

Fig. 3 Low contrast image in B kernel.

(a) $90 \mathrm{kV}, 150 \mathrm{Eff} . \mathrm{mAs}$
(b) $120 \mathrm{kV}, 100 \mathrm{Eff} . \mathrm{mAs}$

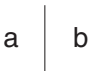

Table 4 Result of low contrast resolution evaluation (90 kV)

\begin{tabular}{|c|c|c|c|c|c|c|c|}
\hline \multirow[b]{2}{*}{ Eff.mAs } & \multicolumn{2}{|c|}{$A$} & \multicolumn{2}{|c|}{ B } & \multicolumn{2}{|c|}{$C$} & \multirow{2}{*}{$\frac{\text { CTDIw }}{\text { mGy }}$} \\
\hline & $\%$ & $\mathrm{~mm}$ & $\%$ & $\mathrm{~mm}$ & $\%$ & $\mathrm{~mm}$ & \\
\hline 35 & 0 & 0 & 0 & 0 & 0 & 0 & 2.1 \\
\hline 50 & 0 & 0 & 0 & 0 & 0 & 0 & 3.0 \\
\hline 100 & 1 & 12 & 1 & 15 & 0 & 0 & 5.9 \\
\hline 150 & 1 & 7 & 1 & 7 & 1 & 7 & 8.9 \\
\hline 200 & 1 & 7 & 1 & 7 & 1 & 7 & 11.9 \\
\hline 300 & 1 & 7 & 1 & 7 & 1 & 7 & 17.8 \\
\hline 350 & 1 & 5 & 1 & 5 & 1 & 7 & 20.7 \\
\hline 400 & 1 & 12 & 1 & 5 & 1 & 5 & 23.7 \\
\hline 500 & 0.5 & 12 & 0.5 & 9 & 0.5 & 12 & 29.6 \\
\hline 600 & 0.5 & 9 & 0.5 & 9 & 0.5 & 9 & 35.6 \\
\hline 700 & 0.5 & 7 & 0.5 & 9 & 0.5 & 9 & 41.5 \\
\hline
\end{tabular}

Table 5 Result of low contrast resolution evaluation (120 kV)

\begin{tabular}{|c|c|c|c|c|c|c|c|}
\hline \multirow[b]{2}{*}{ Eff.mAs } & \multicolumn{2}{|c|}{$A$} & \multicolumn{2}{|c|}{ B } & \multicolumn{2}{|c|}{ C } & \multirow{2}{*}{$\frac{\text { CTDIw }}{\text { mGy }}$} \\
\hline & $\%$ & $\mathrm{~mm}$ & $\%$ & $\mathrm{~mm}$ & $\%$ & $\mathrm{~mm}$ & \\
\hline 35 & 0 & 0 & 0 & 0 & 0 & 0 & 4.5 \\
\hline 50 & 1 & 12 & 1 & 12 & 1 & 12 & 6.5 \\
\hline 100 & 1 & 9 & 1 & 9 & 1 & 9 & 13.0 \\
\hline 150 & 1 & 7 & 1 & 7 & 1 & 7 & 19.4 \\
\hline 200 & 0.5 & 9 & 0.5 & 9 & 0.5 & 12 & 25.9 \\
\hline 300 & 0.5 & 9 & 0.5 & 12 & 0.5 & 12 & 38.9 \\
\hline 350 & 0.5 & 12 & 0.5 & 12 & 0.5 & 12 & 45.4 \\
\hline 400 & 0.5 & 12 & 0.5 & 9 & 0.5 & 12 & 51.8 \\
\hline 500 & 0.5 & 12 & 0.5 & 9 & 0.5 & 12 & 64.8 \\
\hline 600 & 0.5 & 12 & 0.5 & 9 & 0.5 & 9 & 77.8 \\
\hline 700 & 0.5 & 4 & 0.5 & 5 & 0.5 & 7 & 90.7 \\
\hline
\end{tabular}




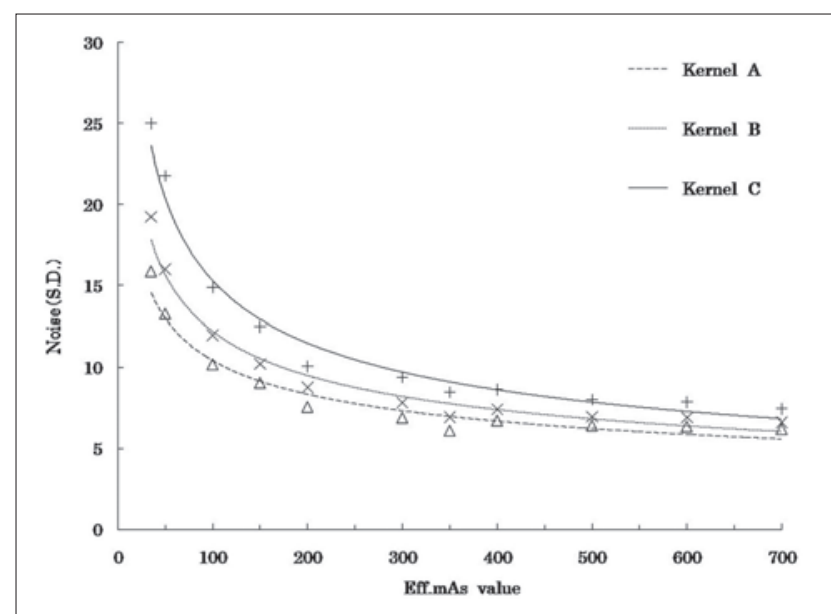

Fig. 4 Relation between mAs value and image noise (90 kV)

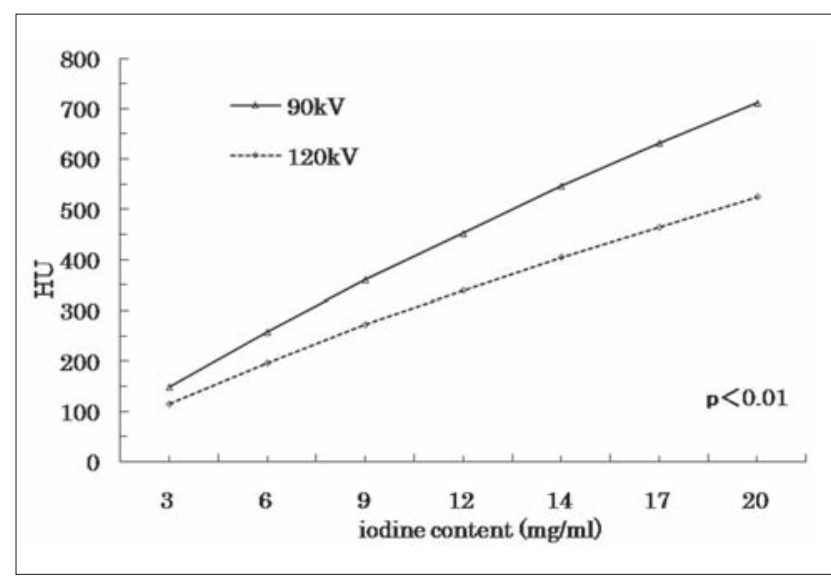

Fig. 6 Relation between iodine contrast medium density and CT numbers.

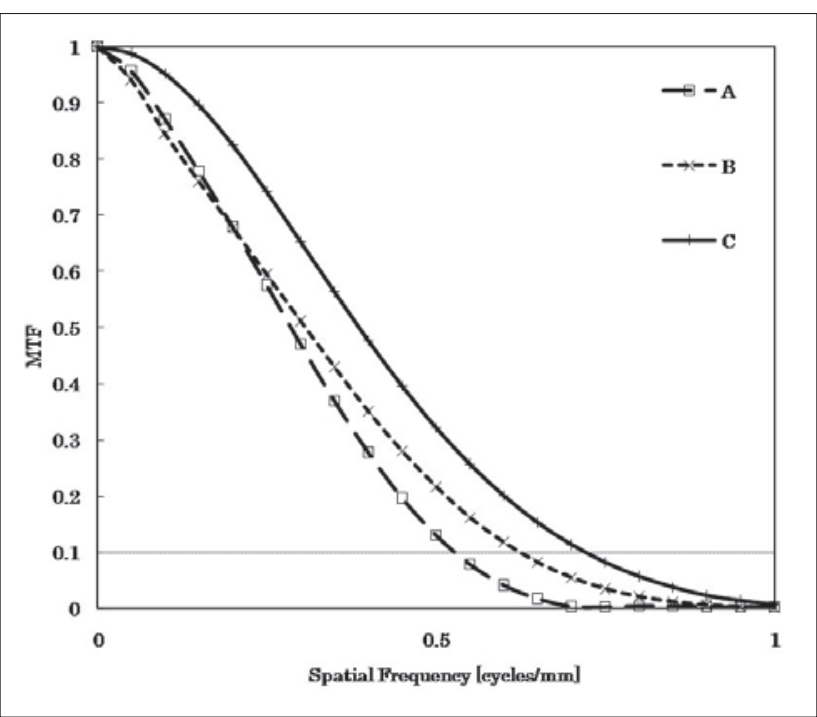

Fig. 8 Resolution characteristics (ultra fast detail).

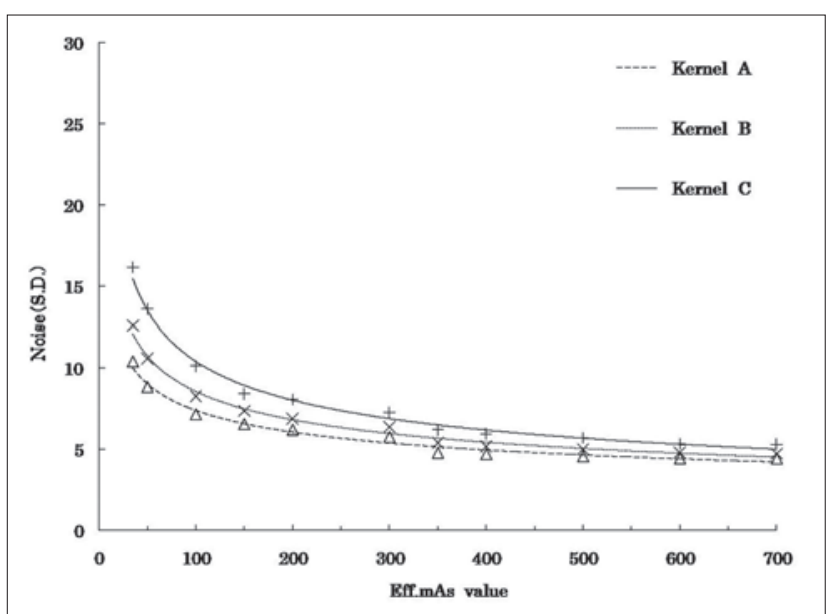

Fig. 5 Relation between $\mathrm{mAs}$ value and image noise (120 kV).

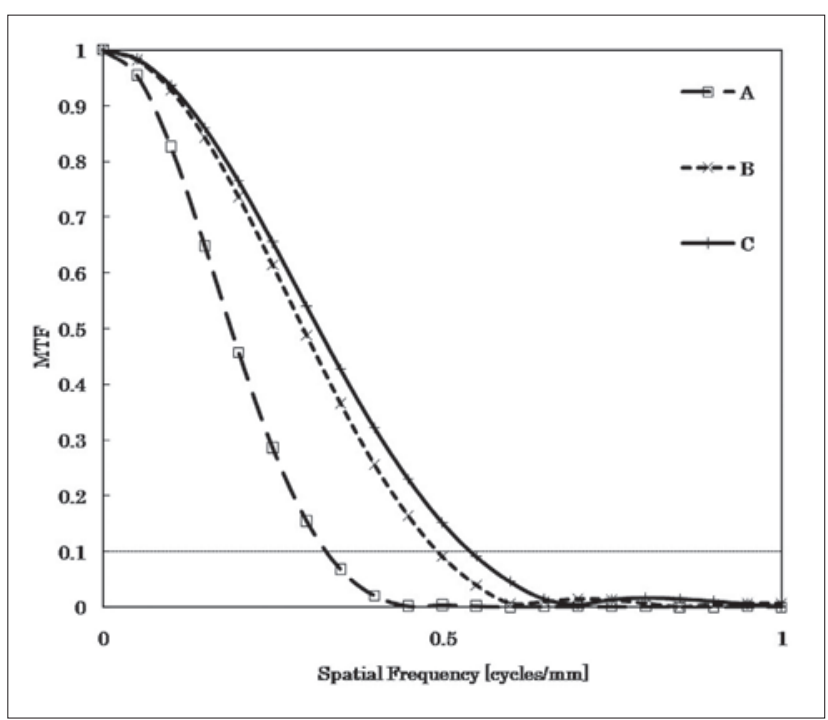

Fig. 7 Resolution characteristics (ultra fast).

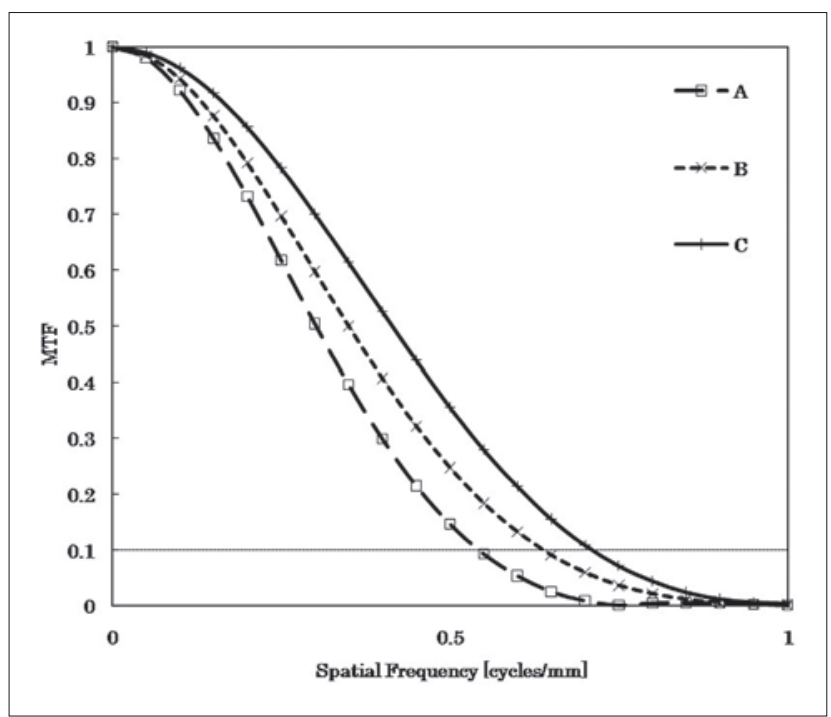

Fig. 9 Resolution characteristics (standard). 


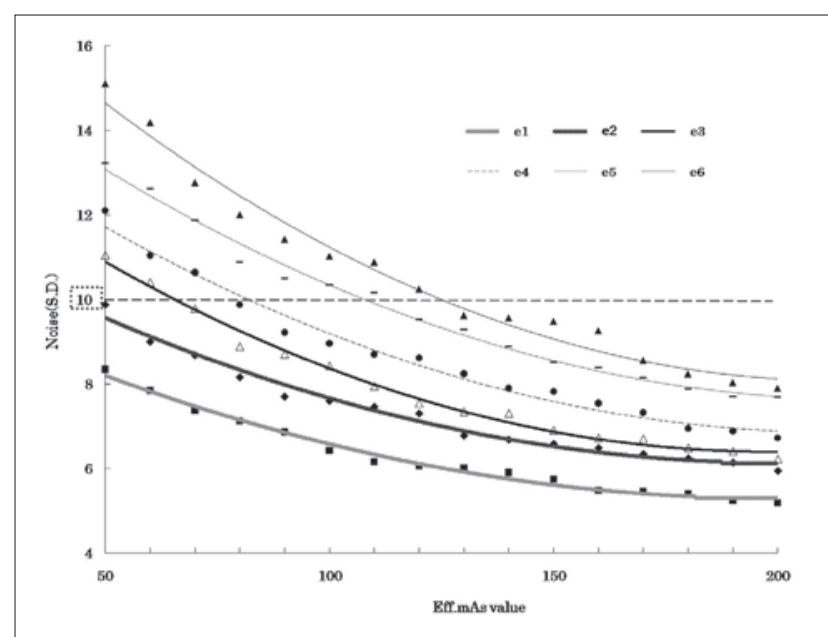

Fig. 10 Relation between Eff.mAs value and image noise.

$120 \mathrm{kV}$ を推奨している8 . 現在われわれの施設で は，体幹部 CTにおいて小児や大人に関係なく管電 圧 $120 \mathrm{kV}$ を使用しているが，今回は $90 \mathrm{kV}$ の使用を 視野に入れて検討を行った。

管電圧では，画像ノイズにおいて，どの管電圧や Kernelの組み合わせでも, Eff.mAs が増加するほど S.D.が低下した。これはEff.mAs の増加とともにX 線光子の量が増加することで，画像に含まれるノイ ズの割合が減少したこと采や， S.D. が既知の定理であ る $1 / \sqrt{\mathrm{DOSE}}$ に比例することからも理解できる。つま り $90 \mathrm{kV}$ を使用し $120 \mathrm{kV}$ と同等の S.D. を得るために は，同等の線量であればよいことが分かる。ただし 今回の検討は小児への適応を前提としており，体幅 がファントムを超える成人のような被写体には言及で きず，ビームハードニングの影響も考慮しなくてはな らないため注意する必要がある。Fig. 4，5より 3 種 類の Kernel のなかで Kernel A が, 最もノイズ軽減に 優れており, 高コントラスト分解能重視の再構成関数 Kernel C が，A に比し約 30\%もノイズの影響を受け やすいことが分かる。このことから被曝低減のみを考 えた場合は, Kernel A を選択するのがよいと思われる. しかし Kernelについては，解像度にも関係するた め,ささざまな要素を勘案したうえで総合的に判断す る必要がある。またヨード造影剤濃度と CT 值の関係 では，どの濃度においても $90 \mathrm{kV}$ の方が CT 值は高 くなった。このことから, $90 \mathrm{kV}$ の実効エネルギーが $120 \mathrm{kV}$ に比し低いことにより，ヨードにおける K 吸 収端である $33 \mathrm{kV}$ 付近に近くなることで, 光電効果が 起こりやすく CT 值が高くなったものと考えられた10). 更に小児では, 頭部や腹腔内の脂肪が少なく臓器も 小さいため, 一般的に画像コントラストが低下する ${ }^{8)}$.

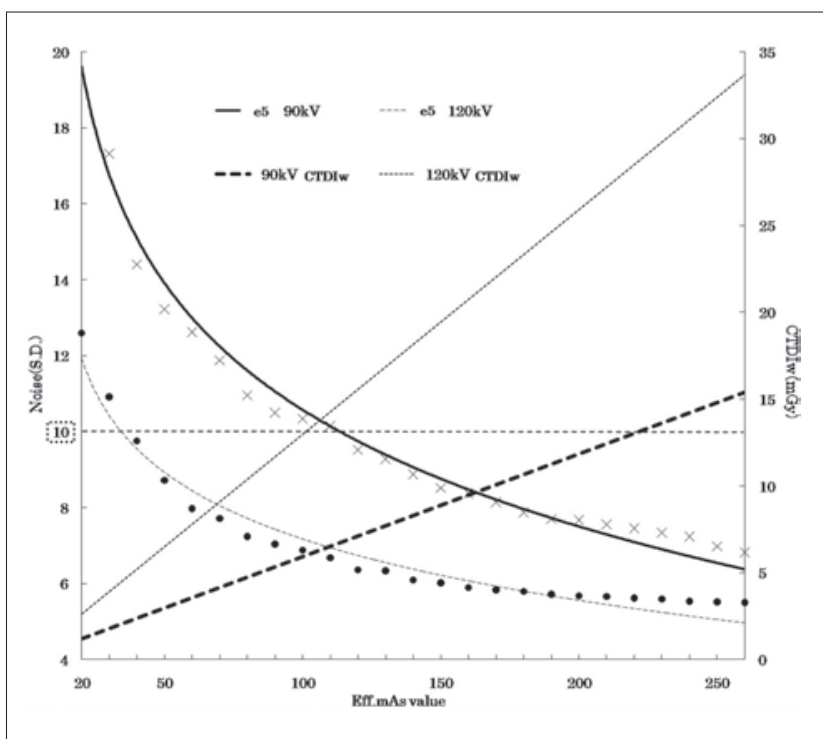

Fig. 11 Relation between image noise and absorbed dose.

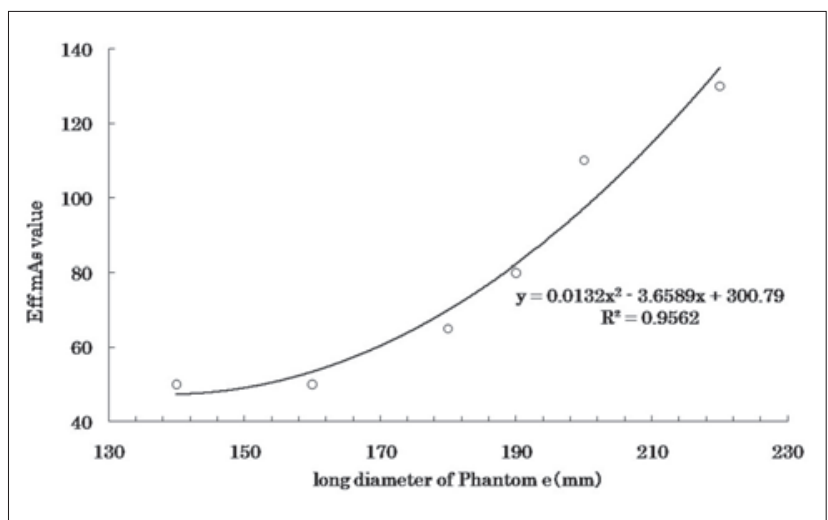

Fig. 12 Eff.mAs value around S.D. 10.

今回検討を行っていないが，臨床的に $90 \mathrm{kV}$ を使用 した方が，血管や結節の視覚的な検出能の向上を経 験することがある。このように $120 \mathrm{kV}$ を選択するよ りも造影効果が向上し，それによる造影剤量低減の 可能性や組織間コントラストの向上も期待できること からも $90 \mathrm{kV}$ を使用する利点があると思われた。

Resolution では，同一 Kernelの MTF 比較におい てUfが劣っていた。これはUf以外にDynamic Focal Spot ${ }^{11}$ が使用されており，View 数の違いが影 響したものと考えられた。またUfおよびUfd は，同 じ回転速度で実験を行ったがUfの方が劣っていた。 これはUf が大焦点で最大 FOV が $500 \mathrm{~mm}$ であるの に対し，Ufd は小焦点で最大 FOVが $250 \mathrm{~mm}$ である ため, View 数の違いに起因するデー夕量および焦点 サイズの違いによる差が現れたものと考えられた。また Ufd, Std ではMTFに有意な差は認められないが, Rotation speed を考慮に入れると，0.42 sec が使用可 能な Ufd の方が，撮影時間短縮が可能である。これ 
により多少の体動や呼吸停止不良下においても, そ の軽減に効果が期待できると思われた。更に同一 Resolutionにおいて, Kernel A, B, Cを MTFで比 較すると, 結果 2-1 項の B) で示したノイズ軽減に優 れていた Kernel A が最も劣っており逆に Kernel Cが 最も優れていた。このことから検討した 3 種類のなか で, Kernel Cが最も高い解像度を持つことが理解で きる。しかしながら Kernel 選択において，それぞれ 特徴があり理解したうえで使用しなくてはならない. 実際検査終了後に再構成をかけ直すことで変更可能 であり，すべての Kernel で再構成することも方法と して考えられる。しかし検査時の煩雑な作業をなくす ことと, 不要な画像データを増やさないために default 設定の Kernel 選択することとした. 先にも述 ベたように，画像ノイズを S.D.10 以下にすることを 前提に撮影条件の検討をしている。そこで小さな被 写体である小児の検査ということを勘案し，可能な 限り多くの情報を持った画像とするため解像度特性 の優れた Kernelの選択を考慮した。その場合，この 3 種類のなかでは Kernel C となるが, Kernel B に比 ベ約 $20 \%$ 画像ノイズが増加してしまい, S.D. 10 以下 に撮影条件を設定しようとすると，Eff.mAsを上げな くてはならず被曝線量の増加につながる。また Kernel A では, Kernel B に比べ約 10\%画像ノイズを 減少させることができるが, 解像度特性が悪く小巟 のような小さな被写体では，画像のボケが無視でき ない。そのため, 画像ノイズおよび解像度特性のバ ランスが最も保たれた Kernel B とした.

撮影線量では，ファントム径が大きくなるに従い， 同一のEff.mAs において S.D.が高くなった。また Eff.mAs の増加に伴い, ファントム別に比較しても S.D. は低くなった。 これはファントム径が大きくなる につれX線の減弱が大きく, 線量が減少するため S.D. が低くなり逆にEff.mAs の増加によって線量が 増加するためS.D. が低くなった。 また $90 \mathrm{kV}, 120 \mathrm{kV}$ とも線量の増加により, 同様な S.D.の減少がみられ ることから，全く同様の CTDIwを比較したものでは ないが, 今回の検討から線質の違いによる S.D.の有 意な差は認められなかった。

これらの結果を踏まえ, 当院における小児体幹部 撮影条件を以下のようにした。管電圧 $90 \mathrm{kV}$, Resolution Ufd, Kernel B, またEff.mAsについて, 当院
では位置決め画像を A-P 方向 $\left(0^{\circ}\right)$ でのみ撮影してお り位置決め画像で実際の体幅を計測することで，Fig． 12 から撮影に必要な Eff.mAs を設定することとした。

以上のように，暫定的に小巟体幹部撮影条件を決 定し，実際に撮影された臨床画像における S.D.の測 定において，ROI を設定した 3 点で若干のバラつき がみられたものの平均 S.D. が 10 を超えることはな かった。ただし，最短撮影時間を得るため 1.313 固定 という High Pitchを使用していることから, 春椎や肋 骨周囲のストリークアーチファクトの影響について考 慮に入れる必要があると思われた。特に大動脈での S.D.は, 9.79 と今回の検討での上限值に近いことか ら, これ以上の被曝低減について今回の検討だけで は難しいと判断した。

\section{4. 結 語}

今回われわれは，小児体幹部撮影条件の検討を行 い，導き出された条件がS.D. 10 を超えない值を示し 現時点で使用していくことに支障がないと考えた。今 後の課題として, 今回得られた撮影条件が楕円ファ ントムから得られたものであり，この範囲を超える大 きな体型に使用ができない. そこでファントムデータ を増やすことで適応範囲の拡大が可能かどうか, ま た今回の結果から得られた画像が, 安定してかつ臨 床上読影に差し支えないものとなっているかデータを 積み重ねて検証を行う必要があると思われた。

加えて今回の検討では, 使用しなかった Brilliance CT16 に搭載されている CT 用自動露出機構 (CT automatic exposure control: CT-AEC) である DoseRight Auto Current Selection(Dose Right ACS), Z-Direction Dose Moderation(Z-DOM) および Dynamic Dose Moderation (D-DOM) といった被曝低減に有用な機能について, DOM は撮影中にリアルタイムで被曝線量低減を行う わけでなく，1 スキャンしてそれを基に次のスキャン に反映されるものであることから，今回得られた体幅 におけるEff.mAs に対してDOMの併用が可能かに ついても検討していく必要があると思われた。

\section{謝 辞}

本研究に際してご助言いただいたフィリップスエレ クトロニクスジャパン 中川 太氏，桑原貞俊氏に深 く感謝いたします。 


\section{参考文献}

1) 辻岡勝美. マルチスライス CTに至る CT の進歩. Innervision 2003; 18(1): 1-8.

2) 宮崎 治. 小児の MDCT; 被曝低減の可能性. 日小児放 線会誌 2002; 18(3): 154-159.

3）野坂俊介. 小児における医療被ばく一特に小児 CTについ て - 4. 特別提言一日本医学放射線学会放射線防護委員会 より一。孜児放線会誌２005; 21(1): 21-24。

4) 平野 透, 熊谷西希子. 疾患から考える腹部造影 CT の 撮影条件設定について. 日放技学誌２005; 61(10): 1380-1384.

5) 東村享治. HCC(肝細胞がん)の検出. Innervision 1997; 12(12): 71-73.

6) 村田勝俊. Multi-Detector Row CT の基礎とアプリケー
ション. Med Imag Tech 2001; 19(1): 17-20.

7）提言. 小児 CT ガイドラインー被ばく低減のために一。 日 本医放会誌 2005; 65(2): 139-141。

8) Donnelly LF, Frush DP. Pediatric multidetector body CT. Radiol Clin North Am 2003; 41(3): 637-655.

9) 辻岡勝美, 花井耕造. 6.4 ノイズ特性. CT 撮影技術学. オーム社，東京，2006: 47.

10）中村 實, 渡部洋一, 金森勇雄, 他. 7-1 光子と物質の相 互作用。医用放射線物理学. 医療科学社, 東京, 2006: 84-86.

11）桑原貞俊. Brilliance CT 最前線のテクノロジー．映像情 報（M）2004; 36(6): 105-113.

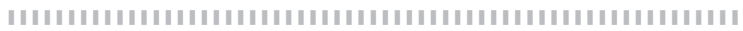

Fig. 1 ファントム
(a) 低コントラスト評価ファントム
(b) ノイズ評価ファントム
(c) MTF 測定ファントム
(d) HU-I ファントム
(e) 楕円ファントム

Fig. 2 臨床画像における S.D. の測定時の ROI 設定位置
(a) 肝右葉
(b) 肝左葉
(c) 大動脈

Fig. 3 各管電圧で撮影した低コントラスト評価ファントム

(a) $90 \mathrm{kV}, 150$ Eff.mAs

(b) $120 \mathrm{kV}, 100 \mathrm{Eff} . \mathrm{mAs}$

なお,どちらも Kernel B 使用

Fig. 4 mAs 值と画像ノイズの関係 $(90 \mathrm{kV}$ の場合)

Fig. $5 \mathrm{mAs}$ 值と画像ノイズの関係(120 kVの場合)

Fig. 6 ヨード造影剂濃度と CT 值の関係

Fig. 7 Kernel を変化させたときの解像度特性の比較(Ultra fast の場合)

Fig. 8 Kernel を変化させたときの解像度特性の比較 (Ultra fast detail の場合)

Fig. 9 Kernel を変化させたときの解像度特性の比較 (Standard の場合)

Fig. 10 各楕円ファントムにおける Eff.mAs と画像ノイズの関係

Fig. 11 同一楕円ファントムおよびEff.mAsにおいて, 管電圧を変化させた場合の画像ノイズおよび吸収線量の関係

Fig. 12 各楕円ファントムにおける S.D. 10 での Eff.mAs との関係

Table 1 HU-I ファントムの各ヨード含有量

Table 2 楕円ファントムの各ファントム径

Table 3 各評価に用いた撮影条件

Ufd: Ultra fast detail, Uf: Ultra fast, Std: Standard

Table 4 低コントラスト分解能の評価結果 (90 kV の場合)

Table 5 低コントラスト分解能の評価結果 $(120 \mathrm{kV}$ の場合) 